рода Пензы / Под общ. ред. О.А. Суховой. Пенза: ГУМНИЦ ПГУ, 2013. 200 с.

5. Кашаев П.В. Из истории возникновения общественного транспорта Пензы // Наша Пенза. 2003. 1723 октября.

6. Ахромеев Д. Пензенскому трамваю - 70 лет! // Молодой ленинец. 2005. - 25 января.

7. Государственный архив Российской Федерации (далее - ГАРФ). Ф. Р-5446. Оп. 1. Д. 224.

8. Сталинское знамя. 1944. - 26 февраля.

9. Полосин Н.И. История пензенского троллейбуса // Краеведение. 1998. № 3-4. С. 71-75.

10. Государственный архив Пензенской области (далее-ГАПО). Ф. Р-847. Оп. 1. Д. 1352.

11. Сталинское знамя. 1945. - 19 августа.

12. ГАПО. Ф. Р-453. ОП. 1а. Д. 214.

13. Сталинское Знамя. 1948. 5 ноября.

14. Филиал РГАНТД. Ф. Р-852. Оп. 2-6. Д. 10.
15. Филиал РГАНТД. Ф. Р-852. Оп. 2-6. Д. 12.

16. Отдел фондов общественно-политических организаций ГАПО. Ф. п-37. ОП. 1. Д. 1060.

17. ГАРФ. Ф. А-314. ОП. 2. Д. 27.

18. ГАРФ. Ф. А-314. Оп. 2. Д. 1207.

19. ГАПО. Ф. Р-2531. ОП. 1. Д. 9.

20. ГАПО. Ф. Р. 453. ОП. 1а. Д. 222.

21. ГАПО. Ф. Р-453. ОП. 1а. Д. 214.

22. ГАРФ. Ф. А-314. Оп. 22. Д. 3309.

23. Государственный архив Пензенской области (ГАПО). Ф. Р-453. ОП. 1а. Д. 221.

24. Сталинское Знамя. 1949. - 7 ноября.

25. ГАПО. Ф. Р-453. ОП. 1а. Д. 230.

26. Молодой Ленинец. 1949. - 7 ноября.

27. Сталинское Знамя. 1949. - 7 ноября.

28. ГАПО. Ф. Р-453. ОП. 1а. Д. 232.

29. ГАПО. Ф. Р-2038. ОП. 1. Д. 1676.

30. Сталинское знамя. 1950. - 31 января.

\title{
ON THE HISTORY OF THE TROLLEYBUS IN PENZA
}

(C) 2016

\author{
A.V. Gorshenin, assistant of the Chair of Humanitarian Disciplines \\ Medical University «Reaviz», Samara (Russia)
}

\begin{abstract}
Urban transport is an integral part of the urban economy. Without public transport it is impossible to imagine the existence of large and medium-sized towns. The analysis in this paper discusses the history of the formation of trolleybus transport in Penza in the 1940s. In pre-revolutionary years local governors wanted to organize work of the tram in Penza, but all ideas remained unrealized. After the October revolution and the beginning of industrialization, city authorities faced the task of the organization of regular intercity transport again. In the 1930s at the request of workers in Penza the narrow-gage city train traffic was organized. But it did not operate long: 2 years later owing to the technical difficulties, it wascancelled. In the years of the Great Patriotic War, in connection with the growth of the city, a need arose regular work of passenger transport. It was decided to build a trolleybus line. The main sources of the research are based on the documents of the Federal and regional archives. They are the State archive of the Russian Federation, the Penza branch of the Russian state archive of scientific-technical documentation, the State archive of the Penza region and the Department of public funds-political organizations GAPO. The archival layer of source materials of local periodicals of the considered years complements this database. Complement the archival layer of source materials is supplemented by local periodicals of the historic period in question. The paper focuses on such processes as design, construction and first few years of operation of the trolleybus in Penza. It includes problems that arose during the construction of the trolleybus route and analyses its role in the economy of Penza.

Keywords: regional history, history of everyday life, city, trolleybus, tram, urban transport, public transport, communal economy, municipal economy, improvement, town planning, Great Patriotic War, post-war period, Penza region, Penza.
\end{abstract}

\section{ЭРОЗИЯ ТРУДОВОЙ ЭТИКИ СОВЕТСКОГО КРЕСТЬЯНСТВА В ПОСЛЕВОЕННОЕ ДЕСЯТИЛЕТИЕ (НА МАТЕРИАЛАХ УЛЬЯНОВСКОЙ ОБЛАСТИ)} (C) 2016

О.Р. Хасянов, кандидат исторических наук, заведующий кафедрой философии и истории

Ульяновская государственная сельскохозяйственная академия имени П.А. Столыпина, Ульяновск (Россия)

Л.Н. Галимова, доктор исторических наук, профессор кафедры гуманитарных и социальных дисциплин Ульяновский институт гражданской авиаџии имени главного маршала авиаџии Б.П. Бугаева, Ульяновск (Россия)

Аннотация. Современные проблемы в аграрной сфере объясняются тем, что в течение десятилетий для государственной аграрной политики было характерным пренебрежение интересов основного производителя деревни, внеэкономическое принуждение к труду, отчуждение от земли и произведенной продукции. Ущемление социальных прав крестьянства неизбежно приводило к урбанизации, миграции населения из деревень.

В статье на основе анализа современной научной литературы и архивных документов, которые впервые вводятся в научный оборот, исследуется сложный процесс разрушения ценностного отношения колхозного крестьянства к труду в общественном хозяйстве. По мнению авторов, материальные трудности сельского общества в военные годы привели к восстановлению в сельском обществе прежних форм хозяйственной деятельности, а именно: единоличной работы на своем земельном участке. Победное завершение войны привело к восстановлению довоенной государственной политики в области сельского хозяйства, но крестьяне продолжали игнорировать общественную работу. Авторы полагают, что государственные кампании, направленные на восстановление 
трудовой дисциплины колхозников, были неудачными, т.к. при отсутствии материальных стимулов к труду колхозники оказались не готовыми к самоотверженному труду в общественном производстве.

Ключевые слова: экономика, аграрная политика, колхоз, трудовые отношения, трудовая этика, крестьянство, сельскохозяйственная артель, трудовая дисциплина, ценность труда, крестьянская этика, эффективность труда.

Важное место в функционировании любой экономической системы отводится эффективности использования трудовых ресурсов. Результативность труда во многом зависит от желания трудоспособного населения участвовать в процессе создания материально значимых общественных благ. В период масштабных социально-экономических изменений, когда протекающие процессы затрагивают не только материальное благополучие общества, но и ценностные ориентиры, не редкими становятся случаи социальной аномалии, когда различные субъекты социальных отношений стремятся удовлетворить свои потребности в ущерб общественным интересам. Таким образом, участие личности в трудовом процессе и создании общественно значимых материальных благ зависит не только от экономической политики государства, но и в равной степени от психофизиологических и интеллектуальных характеристик индивида.

Одной из острых проблем, стоящих перед экономической сферой современной российской государственности, является проблема обеспечения роста производительности труда, которая отстает от экономических показателей наиболее технологически развитых экономик мира. По мнению Президента РФ В.В. Путина, производительность труда в России более чем в два раза уступает по эффективности развитым странам, а сохранение данного положения может стать причиной консервации «однобокой структуры экономики», что не может способствовать росту материального благополучия населения [1].

Задачи повышения производительности труда и эффективности использования трудовых ресурсов решить невозможно без обращения к историческому опыту и научного анализа государственных кампаний, направленных на стимулирование трудовой активности населения.

Длительное время в истории страны одним из ключевых производителей сельскохозяйственной продукции являлось крестьянство, а важнейшая характеристика данной социальной группы заключалась в трудолюбии и смекалке, умении решать сложные хозяйственные вопросы и обеспечивать продовольствием городское население. Но советский аграрный проект, поставивший задачу создания слоя сельских рабочих, отрицающих собственнические ценности, привел к потере сельским обществом социокультурных ориентиров, к пересмотру морально-нравственных категорий и шкалы ценностей представителей крестьянства. Кроме этого, именно село стало для индустриальных центров основным поставщиком трудовых ресурсов, обеспечивающим промышленные предприятия необходимой рабочей силой, а следствием это процесса стало увеличение численного превосходства людей пожилого возраста в социально-демографической структуре сельского социума.

Как отмечает ряд отечественных и зарубежных исследователей, уже в первые месяцы реализации политики коллективизации крестьянство начинает практиковать тактику пассивного сопротивления, что проявлялось в массовом нарушении трудовой дисциплины в колхозном хозяйстве [2, 3, 4]. Одним из механизмов воздействия властей на колхозное крестьянство в предвоенные годы являлось предоставление права на ведение личного подсобного хозяйства (далее - ЛПХ) и выделение крестьянам приусадебного участка, размер которого зависел от выработки членом колхоза установленного минимума трудодней в артели [5]. ЛПХ, как и колхозы, были обязаны предоставлять свою продукцию по заранее установленным ценам специальным государственным заготовительным учреждениям. Как отмечают Х. Кисслер и Е.Г. Корнилов, существование данных механизмов реализации сельскохозяйственной продукции не способствовало росту производительности труда и материального благополучия колхозного крестьянства [4].

В период господства в стране марксистской идеологии исследователи влияния коллективизации и колхозного строя на материально-бытовые условия сельских жителей не были свободны в оценке происходящих явлений и событий. Задача исследователей заключалась в констатации благополучной картины жизни обновленной советской деревни, а проблемы эффективности труда колхозников, их заинтересованности в результатах своей трудовой деятельности, значимости личного подсобного хозяйства в структуре бюджета сельской семьи оставались за рамками исследовательского интеpeca $[6,7,8,9]$. Лишь в 60-70-е гг. XX в. начинают появляться работы, анализирующие изменения в структуре трудовых ресурсов колхозного села, уровень занятости колхозников, их трудозатраты в общественном и в подсобном хозяйстве, а также начинает разрабатываться проблема миграции сельских жителей $[10,11,12$, 13]. В работе В.Б. Островского впервые в советской историографии была предпринята попытка проследить процесс формирования духовного мира крестьянства в социалистическом обществе. Опираясь на обширный материал, автор исследовал процесс изменения характера труда колхозников под влиянием механизации сельскохозяйственного производства [12].

Начиная с середины 80-х гг., отечественная историческая наука выходит за рамки диктата марксистской идеологии, и это обстоятельство позволило по-новому взглянуть на историю советского крестьянства. Одной из первых работ, посвященных анализу процесса раскрестьянивания в послевоенном СССР, является монография О.М. Вербицкой «Российское крестьянство: от Сталина к Хрущеву. Середина 40-х - начало 60-х годов». По мнению автора данной работы, колхозная система была неэффективным механизмом экономической деятельности, которая не могла стимулировать крестьян к труду и обеспечивать продовольственную безопасность страны. Подчеркивая монополистическую роль колхозного хозяйства в сельскохозяйственном производстве СССР, А.А. Хабибуллин указывает на отсутствие заинтересованности колхозников трудиться в общественном производстве. По его мнению, нежелание работать в колхозе было вызвано низким уровнем оплаты труда и высокими налогами [4]. По мнению Т.Д. Надькина, в военные годы именно ЛПХ стали основными источниками получения продоволь- 
ствия крестьянскими семьями и источником налогового обложения государства [2, с. 187].

Начавшаяся Великая Отечественная война временно остановила процесс наступления государства на крестьянство и на традиционный крестьянский уклад жизни. Оказавшись в условиях чрезвычайных материальных лишений и неспособности государственных институтов обеспечить продовольствием сельское население, крестьянство начало активно, не имея на то разрешения региональных и местных властей, расширять размеры своих приусадебных участков. Во многих колхозах отдельные лица имели «два и даже три приусадебных участка» $[14$, л. 5]. Участки засаживались не только овощными культурами, но и бобовыми и зерновыми. Данная практика сохранялась и в послевоенное время. Так, по данным инспектора ЦСУ по Карсунскому району в 1947 г. на приусадебных участках колхозников было засеяно 205 га озимой ржи, 515 га яровой пшеницы, 279 га проса [14, л. 6]. Нередко колхозники на своих приусадебных участках «вели многопольные посевы» $[15$, л. 10]. Реализация данной стратегии выживания привела к тому, что колхозники фактически перестали выходить на работы в колхозах, уделяя основное внимание работам в подсобном хозяйстве. Не случайно, выступая на бюро обкома ВКП(б) 30 декабря 1943 г., первый секретарь Ульяновского обкома И. Терентьев отмечал: «Когда впервые приехал в район (Карсунский. - O.X., Л.Г.), то увидел, что громадное количество людей работало на своих участках, а в колхозе - дети и глубокие старики» $[16$, л. 16]. Трудовая деятельность данной категории сельского населения, по утверждению колхозницы колхоза «Наша сила», была вынужденной мерой, т.к. они отрабатывали «принудиловку, чтобы не отобрали огороды» [15, л. 32].

Как известно, война отрицательным образом сказалась на социально-демографических показателях колхозной деревни. В совокупности с последствиями коллективизации (голод 30-х годов и репрессивная политика государства) в военные годы в среде сельского населения остро ощущался дефицит мужского трудоспособного населения. Так, например, только в отдельно взятой Ульяновской области в 1942 г. общее количество колхозников составляло 675382 человека, а из них 127074 человека были призваны на фронт. В 1944 г. с учетом военных потерь и естественной убыли населения, осложненной военными лишениями, численность колхозников сократилось до 634384 человек. Но данная цифра не отражала реальной численности сельского населения, т.к. 118314 колхозников находились на фронтах Отечественной войны $[17$, л. 4]. Большинство мобилизованных являлись мужчинами трудоспособного возраста. Данные обстоятельства подорвали устойчивость еще экономически неокрепшего колхозного хозяйства. Женщины, старики и дети в условиях острого недостатка сельскохозяйственного инвентаря, тягловой силы и продовольствия не могли обеспечить выполнение колхозами государственных планов по поставкам хлеба и продовольствия, а значит, сельскохозяйственная артель не могла выдать колхозникам продовольствие за отработанные трудодни в нужном объеме. По Ульяновской области урожайность зерновых в 1946 г. по сравнению с 1940 г. снизилась в 4 раза. Если в 1940 г. колхозы области сдали государству 3685860 центнеров зерна, то в 1946 г. - только 834150 центнеров [18, л. 7].
Завершение Великой Отечественной войны вселило в колхозное крестьянство надежду на изменение принципов реализации государственной аграрной политики. Сельские жители, осознавая свой трудовой и людской вклад, внесенный в дело разгрома врага, ожидали роспуска колхозов и предоставления крестьянам хозяйственной самостоятельности. Уже с весны 1945 г. в ряде колхозов Ульяновской области ходили «всевозможные кривотолки» $[15$, л. 10]. Так, в колхозе «ХІІІ лет Октября» колхозница Вилкова говорила колхозникам о том, что союзники «поставили перед товарищем СТАЛИНЫМ вопрос о роспуске колхозов». Пчеловод колхоза «Пролетарий» «говорил среди колхозников о том, что после войны распустят колхозы» [15, л. 10]. В колхозе «На страже» колхозница П. Мишагина «утверждала, что о ликвидации колхозов решен вопрос на конференции в Сан-Франциско» [15, л. 32].

Множество слухов, будораживших сельское общество, свидетельствовали не только о желании крестьян вернуться к принципам хозяйственной деятельности, господствующих в сельском обществе до коллективизации, но и являлись ключевым фактором, разлагающим трудовую дисциплину в колхозной деревне. Колхозники с неохотой выходили на общественную работу. Так, на 1 июня 1945 г. в Астрадамовском районе Ульяновской области не было «ни одного колхозника, выработавшего более 15 трудодней» [15, л. 11], а сам район план весеннего сева выполнил только на $63 \%$ $[15$, л. 14]. В колхозе «Память Куйбышева» Барановского района из 300 трудоспособных колхозников на полевых работах участвовало только 60-70 человек. В соседнем колхозе «Пример» из 150 членов артели за первый период 1945 г. обязательный минимум трудодней не выработали 142 человека [19, л. 36]. На 5 августа 1945 г. по Барановскому району было убрано всего лишь 1500 га зерновых из плана - 23435 га. При этом к обмолоту и сдаче хлеба государству район так и не приступал [19, л. 36].

Переход страны на мирные рельсы развития не изменил отношения большевистского руководства к крестьянству. Как отмечал первый секретарь Ульяновского обкома ВКП (б) И. Терентьев на XIII пленуме обкома 19 марта 1947 г., подъем сельского хозяйства необходимо было обеспечить в кратчайший срок, чтобы «получить обилие продовольствия... сырья для легкой промышленности и накопление необходимых государственных продовольствий», но ни слова не прозвучало об улучшении материально-бытовых условиях колхозников [18, л. 4]. Еще в сентябре 1946 г. с принятием специального Постановления Совета Министров СССР «О мерах по ликвидации нарушений Устава сельскохозяйственной артели» центральное правительство обозначило возвращение к довоенным методам хозяйственноадминистративного руководства сельским хозяйством и взаимодействия с крестьянством. Колхозники должны были проникнуться «всей полнотой ответственности за состояние и развитие колхозов» $[18$, л. 6$]$.

Ключевое место в Постановлении отводилось борьбе с самовольным расширением приусадебных участков колхозников, что, по мнению авторов документа, приводило к уменьшению земельных фондов колхозов, подрывало колхозное благополучие и поощряло «захват общественных земель в колхозах со стороны отдельных рваческих элементов». В Постановлении было 
подчеркнуто, что колхозники и иные элементы, занимающиеся самозахватом колхозной земли, преследовали цель «спекуляции и личной наживы». Региональным властям было рекомендовано до 15 ноября 1946 г. провести ревизию колхозных земель и провести обмер размеров приусадебных участков колхозников, а при обнаружении нарушений «незаконно захваченные земли» возвратить колхозам. Таким образом, правительство стремилось положить конец относительной хозяйственной самостоятельности крестьянских хозяйств и восстановить полный контроль над сельскохозяйственным производством страны.

В первые месяцы реализации кампании по ликвидации нарушений Устава сельскохозяйственной артели в Ульяновской области было выявлено более 50000 случаев самовольного расширения приусадебных участков колхозниками. Цель данной кампании заключалась в принуждении крестьян к исполнению своих трудовых обязанностей в колхозах, не отвлекаясь на личное хозяйство, т.е. правительство было заинтересовано в сохранении у крестьян единственного источника финансового обеспечения в форме артельного хозяйства. Несмотря на жесткие меры давления на сельское общество и массовое выявление случаев нарушения Устава сельскохозяйственной артели рядовыми колхозниками и представителями административно-управленческого персонала колхозов крестьяне продолжали реализовывать хозяйственные практики, утвердившиеся на селе в военные годы. Архивные документы свидетельствуют о том, что «в ряде колхозов госкомиссии несерьезно подходили к обмеру приусадебных участков у колхозников». В Карсунском районе райзо исключило из акта госкомиссии 43 хозяйства колхозников, «у которых было обнаружено излишек земли на общей площади 0,75 га» [20, л. 33]. При обмере приусадебных участков в колхозах «Красный партизан» и «Алга» в 11 хозяйствах установлены случаи самовольного расширения приусадебных участков от 2 до 50 соток [14, л. 5]. В Барышском районе в колхозах «Пробуждение», им. Куйбышева, «Верный путь», «Красный ударник» было самовольно захвачено под приусадебные участки 5,96 га общественных земель [21, л. 40 об.].

Конечно, одним из видимых краткосрочных результатов кампании 1946 г. стало улучшение трудовой дисциплины колхозников, но эффективность их труда оставалась достаточно низкой. Так, в колхозе им. Степана Разина Тиинского района в уборочный период 1947 г. из 111 трудоспособных колхозников в полевых работах участие принимали ежедневно 100-105 человек [14, л. 60]. Необходимо отметить, что значительная часть колхозниц дневную норму выработки не выполняла. Довольно часто трудовой день колхозников начинался в 9-10 часов утра и заканчивался в 7-8 вечеpa $[14$, л. 63].

Увеличение количества колхозников, выходящих на работы в артелях, во многом было связано с тем, что районные власти, разрабатывавшие мероприятия по улучшению трудовой дисциплины, пошли по пути запугивания колхозников. В качестве эффективной меры устрашения был выбран механизм исключения колхозников, не выработавших установленного минимума трудодней, из сельскохозяйственных артелей и, как следствие, изъятия у них приусадебных участков. В колхозе «Фронтовик» Тиинского района 26 октября 1946 г. решением общего собрания, на котором при- сутствовало всего лишь 40\% колхозников, по рекомендации членов госкомиссии были исключены из колхоза 7 колхозников, «как не выработавшие установленного минимума трудодней» [20, л. 34]. По этой же причине 30 октября 1946 г. решением собрания членов сельскохозяйственной артели им. Кирова из колхоза были исключены 22 хозяйства. Среди них оказалась колхозница Седова, являющаяся инвалидом II группы, вдовой участника Отечественной войны и матерью малолетнего ребенка. Исключение из колхоза означало лишь одно - приусадебные участки должны быть возвращены колхозу, а бывшие члены артели оставались без средств к существованию.

Несмотря на ряд жестких мер административного давления на крестьян, проведения серии колхозных собраний с общественным порицанием нарушителей трудовой дисциплины и множество публикаций в прессе о принятых мерах по ликвидации нарушений Устава сельскохозяйственной артели уже летом 1947 г. во многих колхозах Ульяновской области, как и в целом по стране, наблюдается очередная волна падения трудовой дисциплины колхозников. В Барановском районе ежедневно на работы в колхозы не выходило 90-110 человек [22, л. 71]. По отдельным колхозам Карсунского района более $80 \%$ колхозников не выработали в 1947 г. установленного минимума трудодней [14, л. 3]. Так, в колхозе «3-я пятилетка» 318 человек не выработали установленного минимума, что составляла $80 \%$ трудоспособных членов артели. В колхозе «13-й год Октября» не выработали минимума 267 человек, или $93 \%$ [14, л. 3]. Всего по Карсунскому району за 1947 г. не выработали установленного минимума трудодней 7750 человек. К судебной ответственности было привлечено 229 колхозников, из них отбыли наказание только 92 человека, остальные 137 человек несмотря на судебные решения продолжали игнорировать работу в общественном производстве [14, л. 3].

Стремясь справиться с проблемой массового нарушения трудовой дисциплины в сельскохозяйственном производстве, 2 июня 1948 г. Президиум Верховного Совета СССР принимает специальный секретный Указ «О выселении в отдаленные районы страны лиц, злостно уклоняющихся от трудовой деятельности в сельском хозяйстве и ведущих антиобщественный паразитический образ жизни». Согласно тексту Указа, общие колхозные собрания и сходы граждан наделялись правом выносить решения о высылке колхозников, не выработавших установленного минимума трудодней, в районы Лены, Оби, Енисея. Фактически районные власти получили очередной механизм репрессивного воздействия на крестьян. Показательные собрания и сходы граждан, которые должны были поспособствовать восстановлению трудовой дисциплины в артелях, проводились под эгидой и контролем региональных властей $[23$, c. 10$]$.

После получения текста Указа региональные власти в кратчайшие сроки приступили к реализации его положений. Первые общие собрания колхозников о выселении «тунеядцев» и «паразитических элементов» состоялись уже 16 июня 1948 г., а к концу года собрания были проведены во всех районах области. На 1 января 1949 г. из пределов Ульяновской области в отдаленные районы СССР было выслано 326 человек, с которыми добровольно выехало 194 человека членов их семей $[24$, л. 1]. 
Районные и местные власти в лице председателей колхозов и сельских Советов после проведения собраний по Указу от 2 июня 1948 г. и вынесения общественных приговоров о выселении в отдаленные районы СССР лиц, ведущих «паразитический образ жизни», единодушно рапортовали о повсеместном улучшении трудовой дисциплины. Так, секретарь РК ВКП(б) Радищевского района Минеев в своем отчете в Обком партии о проведении общего собрания в колхозе им. Чкалова отмечал, что «трудовая дисциплина и качество труда резко повысились. Если до этого мероприятия выходило на работу 90-100 человек из общего числа трудоспособных 189 человек, сейчас выходят на работу 150-160 человек, причем без приглашения и умоления бригадиров, колхозники приходят к месту работы и просят дать работы» [25, л. 3]. О возросшей производительности труда колхозников сообщал секретарь Сенгилеевского РК Правиков. Так, в колхозе «Луч социализма» до начала реализации положений Указа колхозники во время уборки подсолнечника ручным способом в среднем за день вырабатывали 3-4 сотки на человека, а после проведения в районе 15 собраний стали вырабатывать по 10-12 соток [25, л. 6].

Эффект от очередной государственной кампании, направленной на разрушение жизненных стратегий сельских жителей, оказался скоротечным. Уже летом 1949 г. начинается в очередной раз активно проявляться падение трудовой дисциплины колхозников. В ходе проверки трудового участия колхозников в общественном производстве, организованной областной прокуратурой летом 1949 г., в Радищевском районе было установлено, что «правления колхозов игнорируют постановления ССНК от 13/-42 года, то есть, не проводят борьбу с нарушениями трудовой дисциплины, в результате в этих колхозах большое количество колхозников не выработало установленного минимума трудодней» [26, л. 13]. В колхозе им. 1 Мая Карсунского района из 382 трудоспособных колхозников 123 человека не выработали установленного минимума трудодней в 1949 г. [26, л. 42]. В Базарносызганском районе наблюдались «низкая трудовая дисциплина, невыработка норм, поздний выход и ранний уход с работы» [27, л. 50]. В 1950 г. в Инзенском районе в 12 колхозах более $30 \%$ колхозников не выработали установленного минимума трудодней [28, л. 7]. А в целом по области в 1949 г. 38336 человек, или 16\% трудоспособных колхозников, не выработали законодательно установленного минимума трудодней [28, л. 7].

Об эрозии трудовой этики крестьянства свидетельствовал не только массовый отказ от выхода на общественные работы, но и нарушение трудового распорядка дня во время различных работ в колхозах. Представители прокуратуры, партийные руководители, специальные уполномоченные отмечали поздний выход колхозников на полевые работы. В некоторых колхозах Ульяновской области во время посевных и уборочных работ колхозники приступали к работам не ранее 9-10 часов, а уже в 17-18 часов, прекратив работу, расходились по домам. В некоторых колхозах области обеденный перерыв работников сельского хозяйства растягивался более чем на три часа, так как колхозники для приема пищи и выполнения каких-либо своих личных задач возвращались в свои дома.

Таким образом, проведенный анализ свидетельствует о том, что в послевоенном сельском обществе проходил процесс трансформации ценностных установок сельских жителей. Результаты трудового участия крестьян в общественном производстве не могли удовлетворить материальные потребности сельских жителей. Представители крестьянства ощущали отсутствие заинтересованности государства в их материальном благополучии, не желали работать за трудодни в колхозном хозяйстве. Действенность государственных кампаний, направленных на восстановление трудовой дисциплины и увеличения эффективности труда колхозников, оказалась неэффективной и недолговечной. Труд как ценность перестал служить маркером сельского общества. Отказ от работы в колхозе в глазах колхозного крестьянства не являлся социальной аномалией, а становился нормой социальной действительности. Как и коллективизация, государственные кампании по ликвидации нарушений Устава сельскохозяйственной артели 1946 г. и выселение в отдаленные районы СССР лиц, уклоняющихся от работы в сельскохозяйственных артелях, вызывали в крестьянском обществе негодование. Но они уже не могли изменить подвергнувшуюся эрозии шкалу ценностей крестьянского мира. В частности, труд «на благо социалистической Родины» не являлся значимым элементом жизненной стратегии крестьянства.

\section{СПИСОК ЛИТЕРАТУРЫ:}

1. Путин: главное - повысить производительность труда [Электронный ресурс] // Вести экономика. Точка доступа: http://www.vestifinance.ru/articles/33454 Дата обращения: 23.10 .2015 г.

2. Краев М.А. Победа колхозного строя в СССР. М.: Госполитиздат, 1954. 720 с.

3. Флицпатрик Ш. Сталинские крестьяне. Социальная история Советской России в 30-е годы: деревня. М.: РОССПЭН, 2001. 422 c.

4. Хабибуллин А.А. Социально-экономическое и культурное развитие татарского села в годы довоенных пятилеток (1928-1941 гг.) : автореф. дис. ... канд. ист. наук. Казань, 2013. 30 с.

5. Гущин Н.Я. Сибирская деревня на пути к социализму: социально-экономическое развитие сибирской деревни в годы социалистической реконструкции народного хозяйства (1926-1937 гг.). Новосибирск: Наука, 1973. 517 c.

6. Абрамов Б.А. Партия большевиков - организатор борьбы за ликвидацию кулачества как класса. М.: Госполитиздат, 1952. 135 с.

7. Абросенко К.О. О социалистическом перевоспитании крестьянства. М.: Госполитиздат, 1949. 140 с.

8. Трапезников С.П. Борьба партии большевиков за коллективизацию сельского хозяйства в годы первой сталинской пятилетки. М.: Госполитиздат, 1951. 262 с.

9. Надькин Т.Д. Сталинская аграрная политика и крестьянство Мордовии. М.: РОССПЭН, 2010. 312 с.

10. Анисимов Н. Советское крестьянство. М.: Госполитиздат, 1947. 462 с.

11. ГАУО. Ф. Р-2520. ОП. 7. Д. 73.

12. Овсянников Г.М. Московские большевики в борьбе за коллективизацию сельского хозяйства. М.: Госполитиздат, 1949. 436 с.

13. Островский В.Б. Колхозное крестьянство СССР. Саратов: Издательство Саратовского университета, 1967. $329 \mathrm{c}$.

14. ГАНИ УО. Ф. 8. Оп. 5. Д. 303.

15. ГАНИ УО. Ф. 8. ОП. 1. Д. 129. 
16. Вылцан М.А. Победа колхозного строя и мероприятия партии и государства по улучшению жизни советского крестьянства (1932-1940) // Вопросы истории КПСС. 1968. № 6. С. 42-54.

17. Государственный архив Новейшей истории Ульяновской области (ГАНИ УО). Ф. 8. ОП. 1. Д. 119.

18. ГАНИ УО. Ф. 8. ОП. 3. Д. 233.

19. ГАНИ УО. Ф. 8. ОП. 3. Д. 230.

20. ГАНИ УО. Ф. 8. Оп. 5. Д. 293.

21. ГАНИ УО. Ф. 8. ОП. 6. Д. 147.

22. ГАНИ УО. Ф. 8. ОП. 5. Д. 2.
23. Хасянов О.Р. «...Их нужно выгнать из села вместе с их семьями...»: практика реализации Указа Президиума Верховного Совета СССР от 2 июня 1948 г. в Ульяновской области в документах государственных архивов. Ульяновск, 2015. $254 \mathrm{c.}$

24. ГАНИ УО. Ф. 8. ОП. 6. Д. 404.

25. ГАНИ УО. Ф. 8. ОП. 6. Д. 220.

26. ГАНИ УО. Ф. 8. ОП. 7. Д. 495.

27. Государственный архив Ульяновской области (ГАУО). Ф. Р-2520. ОП. 7. Д. 65.

28. ГАУО. Ф. Р-2520. ОП. 7. Д. 70.

\section{EROSION WORK ETHIC OF THE SOVIET PEASANTRY IN THE POSTWAR DECADES (ON MATERIALS OF THE ULYANOVSK REGION)}

(C) 2016

O.R. Khasyanov, candidate of historal sciences, head of the Chair of Philosophy and History

Ulyanovsk State Agricultural Academy named after P.A. Stolypin, Ulyanovsk (Russia)

L.N. Galimova, doctor of historal sciences, professor of the Chair of Humanitarian and Social Disciplines

Ulyanovsk Institute of Civil Aviation named after Chief Marshal of Aviation B.P. Bugaev, Ulyanovsk (Russia)

Abstract. Modern problems in the agricultural sector are rooted in the fact that for decades the state agricultural policy was characterized by neglect of the interests of the main producer, non-economic coercion to labour, alienation from the land and produced goods, infringement of social rights of the peasantry which inevitably led to urbanization, population migration from villages.

On the basis of the study of the scientific literature and archival documents which have been analysed for the first time, the complex process of destruction of the collective farmers's attitude to work in the public sector is explored. According to the author, the material difficulties of rural society in the war years led to the recovery in the agricultural society of previous forms of economic activity, namely the one-man operation in its stead. The victorious conclusion of the war led to the restoration of the pre-war state policy in the field of agriculture, but farmers continued to ignore social work. The author believes that public campaigns aimed at the restoration of collective farmers's labor discipline were unsuccessful because in the absence of material incentives the collective farmers were not ready for selfless labor in social production.

Keywords: economics, agricultural policy, farm, labor relations, work ethic, the peasantry, the agricultural artel, work ethic, value of work, the peasant ethics, and the efficiency of labor.

\section{УДК $947(571.53) 3$}

\section{ДЕМОГРАФИЧЕСКИЕ ПРОБЛЕМЫ ИНДУСТРИАЛЬНЫХ ГОРОДОВ ИРКУТСКОЙ ОБЛАСТИ В 1990-Е ГОДЫ}

(C) 2016

Т.П. Урожаева, кандидат исторических наук, сотрудник лаборатории исторической демографии Иркутский государственный университет, Иркутск (Россия)

\footnotetext{
Аннотащия. В статье автор анализирует проблемы демографического развития промышленных городов Приангарья в 1990-е гг. В частности, акцентируется внимание на негативных тенденциях в естественном и миграционном движении городского населения, которые, в свою очередь, привели к депопуляции. Распределение муниципальных образований Иркутской области по значению общего коэффициента смертности позволяет выделить лишь наиболее общие закономерности. Минимальный уровень общей смертности фиксировался в юго-восточных и центральных районах области, а также в большинстве крупных и средних городов. Наиболее высокие значения общего коэффициента смертности приходились на северные районы области и ряд сельских районов и моногородов центральной и восточной части области. Преимущественно, это депрессивные муниципальные образования, имеющие моноотраслевую экономику. По мнению автора, причины демографической нестабильности индустриальных городов во многом были заложены в советский период и были связаны с практикой привлечения населения и заселения районов нового промышленного освоения. Экономический кризис и обострение социальных проблем в 1990-е гг. серьезно осложнили демографическое развитие городского населения в регионе. Демографический кризис 1990-х гг. можно было заметно сгладить, если бы на уровне федерального центра и региона принимались меры по прекращению устойчивой депопуляции населения. В условиях краха политической системы демографическая политика на долгие годы была отодвинута на второй план. В результате демографический кризис, который зародился еще в 1980-х гг., в полной мере проявился на уровне региона в первое постсоветское десятилетие.

Ключевые слова: городское население, моногорода, демографический кризис, коэффициент рождаемости и смертности, миграционная убыль населения, трудоспособное население, депопуляция, старение населения, демографическая политика, депрессивные муниципальные образования.
} 